\title{
Stanovení nákladů na vlastní kapitál - model CAPM
}

\author{
Petr Vaňkát \\ Vedoucí práce: Ing. Anna Staňková, CSc.

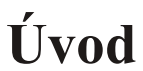

Jednou z podstatných složek ocenění podniku pomocí metody diskontovaného peněžního toku (DCF) a zároveň jednou z nejobtížnějších je stanovení diskontní míry pro účely aktualizace budoucích peněžních toků. I malé odchylky diskontní míry mohou způsobit značné změny v čisté současné hodnotě očekávaných peněžních toků a tím zásadně ovlivnit výsledné ocenění podniku. Celá problematika je navíc umocněna relativní obecností oceňovacích standardů a $\mathrm{z}$ ní plynoucí poměrně značná libovůle v praxi, respektive snaha odhadců si výpočet diskontní míry ulehčit či upravit propočet tak, aby byla dosažena žádoucí hodnota.

Při stanovení diskontní míry v modelech DCF se nevyhneme stanovení nákladů na vlastní kapitál (NVK). Tyto náklady jsou do jisté míry specifické, kromě dividend se za ně explicitně neplatí. Jsou determinovány požadavky investorů na výnosnost při daném riziku. Tyto požadavky jsou odvozeny od možného alternativního výnosu se stejným rizikem investice. $\mathrm{V}$ principu je tedy jejich propočet stejný jako náklady na cizí kapitál, které jsou však oproti NVK daleko zřejmější a jejich stanovení je méně obtížné. Při určování NVK se obecně může vyjít z teorie kapitálového trhu, nebo lze využít vlastní odhady. Př́stup, který vychází z teorie kapitálového trhu, je typický pro anglosaské země a stále více se prosazuje i v Evropě. V současné době se v praxi nejvíce uplatňuje přístup, který vychází z modelu oceňování kapitálových aktiv (Capital Asset Pricing Model - CAPM), který vytvořili nezávisle na sobě v 60. letech W. F. Sharpe, J. Lintner a J. Mosin.

V této práci se budeme zabývat konkrétním stanovením NVK. Zaměříme na situaci, kdy jsou NVK kalkulovány pomocí zmíněného modelu CAPM. Budeme uvažovat pouze př́stup ex post. Tedy předpokládáme, že minulost je dobrým základem pro odhad budoucnosti. Tzn., budeme se snažit na základě dat z minulosti odhadnout hodnoty některých veličin. Př́istup ex ante nebudeme uvažovat, i když je považován za teoreticky správnější. ${ }^{1}$ Při vlastním výpočtu můžeme vycházet $\mathrm{z}$ dat domácího kapitálového trhu (myšleno z hlediska oceňované firmy) nebo můžeme vyjít $\mathrm{z}$ dat světového nejlépe amerického trhu a rizikovou prémii navýšit o rizikovou prémii země. Přístup, kdy vycházíme $\mathrm{z}$ dat amerického kapitálového trhu, je v podmínkách ČR vzhledem k rozvinutosti českého kapitálového trhu obecně považován za vhodnější. ${ }^{2}$

Právě na př́kladu ČR se pokusíme zjistit, do jaké míry se liší výsledky kalkulace NVK, jestliže nejprve k výpočtu použijeme data českého kapitálového trhu a poté data amerického kapitálového trhu s následnou úpravou o rizikovou prémii ČR. NVK budeme počítat pro společnosti ČEZ, a.s. (dále ČEZ), Telefónica O2 Czech Republic, a.s. (dále O2),

1 Mařík, M.: Odhad rizikové prémie kapitálového trhu metodou ex ante jako cesta ke zdokonalení kalkulací diskontní míry. Odhadce a oceňování majetku, 2005, roč. 11, č. 4, s. 6.

2 Mařík, M. a kol.: Metody oceňování podniku. Praha, Ekopress 2003, s. 186. 
Philip Morris ČR a.s. (dále Philip Morris) a Zentiva N.V., a.s. (dále Zentiva). Výpočet NVK bude proveden k 1. 1.2006. ${ }^{3}$ Práce je pojata spíše aplikačně a předpokládá se čtenářova znalost teorie CAPM. Data pro jednotlivé výpočty budeme čerpat z veřejných zdrojů. Veškeré výpočty budeme zaokrouhlovat na dvě desetinná místa.

\section{Výpočet NVK pomocí modelu CAPM - český kapitálový trh}

\section{Formulace modelu}

Vzhledem k tomu, že model CAPM je obecně známý, včetně předpokladů ze kterých vychází, není třeba ho zde podrobně vysvětlovat. Dříve než pokročíme dále, musíme přijmout i s ohledem na rozsah práce výchozí podmínku, že jsou splněny všechny předpoklady použitelnosti modelu CAPM ke kalkulaci NVK, především skutečnost, že uvažujeme tzv. diverzifikovaného investora. Při odhadu NVK se vychází z tzv. př́imky trhu cenných papírů (security market line - SML). Grafické znázornění SML vidíme na obrázku č. 1. Na osu x vynášíme koeficient beta akcie oceňovaného podniku a na osu y výnosnost akcie námi oceňovaného podniku.

\section{Obrázek č. 1: Přímky trhu cenných papírů}

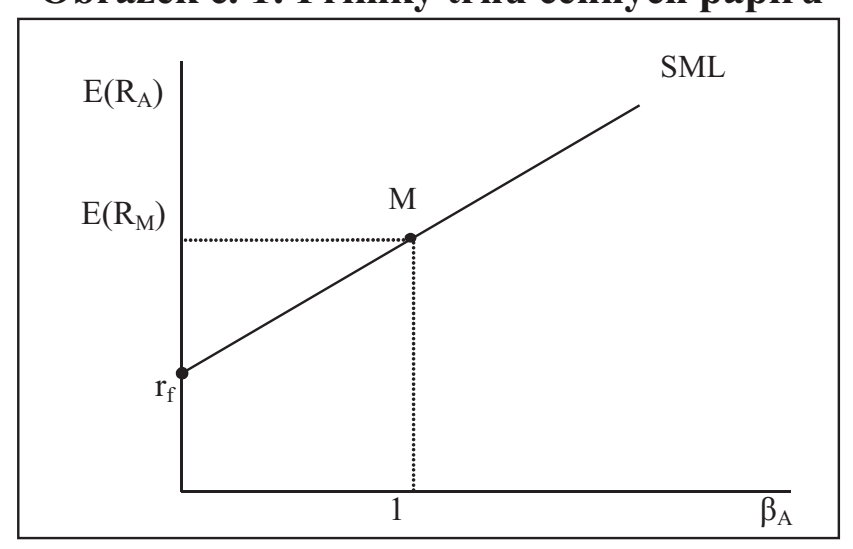

Matematicky můžeme SML zapsat ve tvaru:

$$
E\left(R_{A}\right)=r_{f}+\beta_{A}\left(E\left(R_{M}\right)-r_{f}\right),
$$

kde: $\quad E\left(R_{A}\right)$ je střední očekávaná výnosnost akcie námi oceňovaného podniku;

$\mathrm{r}_{\mathrm{f}} \quad$ je bezriziková výnosnost;

$\mathrm{E}\left(\mathrm{R}_{\mathrm{M}}\right)$ je střední očekávaná výnosnost kapitálového trhu (tzv. tržního portfolia);

$\hat{a}_{\mathrm{A}} \quad$ je koeficient beta akcie námi oceňovaného podniku.

Takto vyjádřená $E\left(R_{A}\right)$ je pak ztotožňována s NVK. Pokusíme se odhadnout proměnné této rovnice a využijeme $\mathrm{k}$ tomu nejprve data $\mathrm{z}$ českého kapitálového trhu.

\section{Odhad dílčích proměnných}

\section{Bezriziková úroková míra}

Obecně platí, že za bezrizikovou úrokovou míru lze považovat výnosnost státních dluhopisů, které nenesou kupón. Teorie oceňování přitom doporučuje, aby bezriziková úroková

3 Telefónica O2 Czech Republic, a.s. tehdy provozovala své aktivity pod názvem ČESKÝ TELECOM, a.s., člen skupiny Telefónica. 
míra byla odvozena $z$ aktiv, jejichž délka životnosti se přibližuje životnosti aktivům oceňovaného podniku. Pro český kapitálový trh se doporučuje používat ${ }^{4}$ pro stanovení bezrizikové úrokové míry výnos do doby splatnosti indexu gpri3+, což je výnosový index státních dluhopisů se zbývající dobou splatnosti 3 a více let, který uvádí Patria Online, a. s. K 1. 1. 2006 byl výnos do doby splatnosti indexu gpri3+3,50\%.

\section{Riziková prémie trhu}

Riziková prémie trhu je definována jako $\left(E\left(R_{M}\right)-r_{f}\right)$. V praxi se za $E(R M)$ dosazuje dlouhodobá výnosnost tržního indexu. V našem př́ípadě vyjdeme z indexu PX 50. Při stanovení jeho výše je třeba vyřešit následující metodické otázky. První otázka se vztahuje $\mathrm{k}$ délce období, za které je průměrný výnos stanoven. I když jsou starší data méně relevantní, kloní se teorie k názoru použít období co možná nejdelší. Toto doporučení plně využijeme až v kapitole 0, kdy budeme počítat NVK na základě dat amerického kapitálového trhu. V př́padě českého kapitálového trhu je však situace výrazně odlišná. Ve výročních zprávách Burzy cenných papírů Praha lze dohledat hodnotu indexu PX 50 k 31. 12. 1993, jako první období použijeme tedy konec roku 1993.

Dále je třeba určit, zda pracovat s geometrickým či aritmetickým průměrem. Zde se zdá, že ve znalecké obci mírně převažují argumenty zastánců geometrického průměru. ${ }^{5} \mathrm{Na}-$ dále budeme tedy historické výnosnosti počítat pomocí geometrického průměru. Hodnoty indexu PX 50 ke konci jednotlivých let a průměrnou výnosnost vypočtenou pomocí geometrického průměru nalezneme $\mathrm{v}$ tabulce č. 1 . Tržní dividendu zanedbáváme. Za rf opět dosadíme gpri3+. Riziková prémie je tedy $E\left(R_{M}\right)-r_{f}=6,33 \%-3,50 \%=2,83 \%$.

Tabulka č. 1: Průměrná velikost indexu PX 50

\begin{tabular}{|c|c|c|}
\hline konec roku & index PX 50 (PX) & koeficient růstu \\
\hline \hline 1993 & 705,2 & \\
\hline 1994 & 557,2 & 0,790130459 \\
\hline 1995 & 425,9 & 0,764357502 \\
\hline 1996 & 539,6 & 1,266964076 \\
\hline 1997 & 495,3 & 0,91790215 \\
\hline 1998 & 394,2 & 0,795881284 \\
\hline 1999 & 489,7 & 1,242262811 \\
\hline 2000 & 478,5 & 0,977128854 \\
\hline 2001 & 394,6 & 0,824660397 \\
\hline 2002 & 460,7 & 1,167511404 \\
\hline 2003 & 659,1 & 1,430649012 \\
\hline 2004 & 1032 & 1,565771507 \\
\hline 2005 & 1473 & 1,427325581 \\
\hline \multicolumn{2}{|c|}{ geometrický průměr } & 1,063304219 \\
\hline \multicolumn{2}{|c|}{ průmérná výnosnost } \\
\hline
\end{tabular}

Zdroj: Výroční zpráva Burzy cenných papírů Praha 2005, vlastní výpočty.

4 Mař́k, M. a kol.: Metody oceňování podniku. Praha, Ekopress 2003, s. 184.

5 Mařík, M. a kol.: Metody oceňování podniku. Praha, Ekopress 2003, s. 186. 


\section{Koeficient beta}

Koeficient $\hat{a}_{\mathrm{A}}$ vyjadřuje citlivost akcie oceňovaného podniku na změnu výnosové míry tržního portfolia. Koeficient $\hat{\mathbf{a}}_{\mathrm{A}}$ je dán vzorcem:

$$
\beta_{A}=\frac{\operatorname{COV}\left(R_{A}, R_{M}\right)}{\left(S_{M}\right)^{2}},
$$

kde: $\operatorname{COV}\left(\mathrm{R}_{\mathrm{A}} \mathrm{R}_{\mathrm{M}}\right)$ je kovariance mezi výnosem akcie oceňovaného podniku

$$
\left(\mathrm{S}_{\mathrm{M}}\right)^{2} \quad \text { je rozptyl výnosnosti tržního portfolia. }
$$

Při vlastním propočtu využijeme historický přístup, kdy vypočítáme $\hat{a}_{\mathrm{A}}$ za minulost a předpokládáme, že minulost bude dobrým základem pro budoucí odhad. Ovšem i na rozvinutých kapitálových trzích je $\hat{a}_{\mathrm{A}}$ relativně nestabilní. Lepších výsledků dosáhneme, pokud použijeme betu vypočtenou za celé odvětví oceňovaného podniku. Takto stanovená beta by měla být statisticky více spolehlivá. S odvětvovou betou budeme postupovat i my. Bety za jednotlivá odvětví jsou publikovány jako nezadlužené, nebo jako zadlužené. Vyjdeme z nezadlužených bet a odlišnosti v kapitálové struktuře zohledníme podle následujícího vzorce: ${ }^{6}$

$$
\beta_{Z}=\beta_{N}\left(1+(1-d) \frac{C K}{V K}\right)
$$

kde: $\hat{a}_{\mathrm{Z}}$ je beta vlastního kapitálu u zadlužené firmy;

$\hat{a}_{\mathrm{N}} \quad$ je nezadlužená beta odvětví;

CK je tržní hodnota cizí kapitálu;

VK je tržní hodnota vlastního kapitálu;

d je sazba daně z př́ijmu.

Nezadluženou betu ${ }^{7}$ pro naše odvětví získáme na stránkách profesora Damodarana. ${ }^{8}$ Pro společnost ČEZ volíme nezadluženou betu odvětví „Electric - Integrated“ pro Evropu a to ve výši $0,62 .{ }^{9} \mathrm{~V}$ důsledku rozvinutosti českého kapitálového trhu prakticky ani jinou možnost nemáme. Obdobně postupujeme u dalších společností. Zvolená odvětví a hodnoty nezadlužených beta pro jednotlivé společnosti můžeme vidět v tabulce č. 2 .

Tabulka č. 2: Nezadlužené â pro jednotlivé společnosti

\begin{tabular}{|l|c|c|}
\hline \multicolumn{1}{|c|}{ Společnost } & Odvětví & $\beta_{\boldsymbol{N}}$ \\
\hline \hline ČEZ & Electric - Integrated & 0,62 \\
\hline Zentiva & Medical-Drugs & 1,04 \\
\hline Philip Morris & Tobacco & 0,51 \\
\hline O2 & Telecom Services & 1,12 \\
\hline
\end{tabular}

Zdroj: http://www.damodaran.com.

6 Za předpokladu, že â pro cizí kapitál je nulová, viz Mařík, M. a kol.: Metody oceňování podniku. Praha, Ekopress 2003, s. 190.

7 Bety jsou počítány na základě měsíčních výnosů jednotlivých akcií za posledních 5 let a poté zprůměrovány.

8 Professor of Finance and David Margolis Teaching Fellow at the Stern School of Business at New York University, http://.www.damodaran.com.

9 http://www.stern.nyu.edu/ adamodar/pc/datasets/betaEurope.xls (jedná se o bety publikované v lednu 2006). 
Vliv kapitálové struktury promítneme dle výše uvedeného vzorce. Otázka zní, jak určit poměr CK a VK, respektive podíl CK a VK na celkovém kapitálu. S touto otázkou opět souvisí několik problémů. Za prvé lze předpokládat, že se kapitálová struktura bude v budoucnu měnit. Za druhé tento poměr by měl být stanoven na základě tržních hodnot VK a CK. Tržní hodnotu VK však neznáme, ta je výsledkem až vlastního ocenění podniku. Celá problematika je jak v teorii tak praxi oceňování řešena, nicméně značně přesahuje rozsah této práce.

My celou situaci výrazně zjednodušíme. Při stanovení poměru CK a VK budeme vycházet z účetních hodnot. Tento přístup není zas tak neobvyklý, respektive má své zastánce. Přesto jednoznačně převládá názor, že by se měly používat tržní hodnoty. Dále budeme předpokládat, že výchozí podíl $\mathrm{CK}$ a $\mathrm{VK}$, vypočtený z účetních dat, bude odpovídat zpětně dopočítanému podílu hodnoty netto ${ }^{10}$ a CK. Podíl CK a VK tedy zjistíme jako podíl účetní hodnoty VK a CK k 1. 1. 2006. Ještě dodejme, že do výpočtu výše CK nevstupují krátkodobé závazky a pasivní položky časového rozlišení. ${ }^{11}$ A předpokládáme, že veškerý majetek v rozvaze je provozně nutný. Tím se vyhneme některým úpravám na straně pasiv. Pokud uvedené předpoklady použijeme při výpočtu s českými daty i při výpočtu s americkými daty, nebudou obecné závěry této práce ohroženy. Data pro výpočet získáme z auditovaných konsolidovaných účetních závěrek za rok 2005.

Pro společnost ČEZ nám z konsolidované rozvahy vyšel podíl $\frac{C K}{V K}$. Sazbu daně Z př́ijmu předpokládáme ve výši $24 \%$. Zadlužená beta je potom $\beta_{Z}=0,62 \cdot(1+(1-0,24) \cdot 0,43)=0,82$. Obdobně postupujeme u dalších společností. Výsledky propočtů vidíme v tabulce č. 3 .

Tabulka č. 3: Zadlužené â

\begin{tabular}{|l|c|c||}
\hline \multicolumn{1}{|c|}{ Společnost } & CK/VK & $\beta_{Z}$ \\
\hline \hline ČEZ & 0,43 & 0,82 \\
\hline Zentiva & 0,25 & 1,24 \\
\hline Philip Morris & 0,02 & 0,52 \\
\hline O2 & 0,19 & 1,28 \\
\hline
\end{tabular}

Zdroj: http://www.damodaran.com, výroční zprávy, vlastní výpočty.

\section{Výpočet NVK}

Nyní využijeme předešlé odhady ke kalkulaci NVK. Nejprve stanovíme NVK pro společnost ČEZ. Vyjdeme z př́mky trhu cenných papírů, přičemž $\mathrm{E}\left(\mathrm{R}_{\mathrm{A}}\right)$ ztotožňujeme s NVK. Dosadíme do vzorce $N V K=r_{f}+\beta_{A}\left(E\left(R_{M}\right)-r_{f}\right)$ a dostaneme $N V K=3,50 \%+0,82 \%$. $\cdot 2,83 \%=5,82 \%$. NVK společnosti ČEZ tedy jsou $5,82 \%$. Stejným postupem spočítáme NVK pro další společnosti. Konkrétní hodnoty vidíme v následující tabulce č. 4.

10 Hodnota netto = hodnota brutto - tržní hodnota úročeného CK. Hodnota brutto je výsledek ocenění podniku jako celku.

11 Mař́k, M. a kol.: Metody oceňování podniku. Praha, Ekopress 2003, s. 146. 
Tabulka č. 4: NVK pro jednotlivé společnosti

\begin{tabular}{|l|c|}
\hline \multicolumn{1}{|c|}{ Společnost } & NVK (\%) \\
\hline \hline ČEZ & 5,82 \\
\hline Zentiva & 7,01 \\
\hline Philip Morris & 4,97 \\
\hline O2 & 7,12 \\
\hline
\end{tabular}

Dostali jsme hodnoty NVK pro zvolené společnosti. Při výpočtu rizikové prémie jsme vycházeli z dat českého kapitálového trhu. Pro výpočet $\hat{a}_{\mathrm{A}}$ jsme využili hodnoty, které poskytuje na svých stránkách profesor Damodaran. Jedná se o odvětvové nezadlužené bety, které jsme převedli na zadlužení dané společnosti. Nyní přejdeme k druhému př́stupu, kdy využijeme data amerického kapitálového trhu a úpravu o rizikovou prémii země.

\section{Výpočet NVK pomocí modelu CAPM - data amerického kapitálového trhu}

\section{Formulace modelu}

Jedná se o př́stup, kdy NVK kalkulujeme na základě dat amerického kapitálového trhu. Principielně vycházíme z modelu CAPM a celý model upravujeme o rizikovou prémii země (RPZ), což lze formálně zapsat takto:

$$
N V K=r_{f}+\beta_{Z} \cdot R P T+R P Z,
$$

kde: $\quad r_{f} \quad$ je bezriziková výnosnost;

$\hat{a}_{Z} \quad$ je odvětvová beta přenesená z USA a upravená na zadlužení v tržních cenách konkrétního podniku;

RPT je riziková prémie kapitálového trhu v USA;

RPZ je riziková prémie země.

Pokusíme se co nejpřesněji odhadnout jednotlivé hodnoty proměnných v rovnici. Kromě rizikové prémie země, jsme ostatní proměnné charakterizovali v předchozích kapitolách. Proto se u těchto proměnných omezíme na nenutnější poznámky k vlastnímu výpočtu.

\section{Odhad dílčích proměnných}

\section{Bezriziková výnosnost}

Za bezrizikovou výnosnost se doporučuje ${ }^{12}$ dosazovat aktuální výnosnost 10letých vládních dluhopisů Spojených států, kterou získáme na stránkách profesora Damodarana v sekci updated data. K 1. 1. 2006 uvažujeme hodnotu 4,99 \%. ${ }^{13}$ Tato hodnota byla spočítána jako geometrický průměr.

12 Mařík, M. a kol.: Metody oceňování podniku. Praha, Ekopress 2003, s. 184.

13 http://www.stern.nyu.edu/ adamodar/pc/datasets/histretSP.xls (jedná se o data publikovaná v lednu 2006). 


\section{Odvětvová beta z USA}

Nejprve určíme odvětvovou betu pro ČEZ. Využijeme opět data na stránkách profesora Damodarana. Volíme nezadluženou betu odvětví „Electric Utility“ pro USA a to ve výši 0,54 (průměr za West, East a Central). ${ }^{14}$ Tuto odvětvovou betu převedeme na zadlužení společnosti dle vzorce uvedeného v kapitole. Výpočet podílu CK a VK (včetně předpokladů) byl rovněž proveden $v$ kapitole 0 . Sazbu daně $z$ příjmu předpokládáme opět ve výši $24 \%$. Zadlužená beta je potom $\beta_{Z}=0,54 \cdot(1+(1-0,24) \cdot 0,42)$. Stejný postup aplikujeme u dalších společností. Výsledné hodnoty vidíme v tabulce č. 5 .

Tabulka č. 5: Zadlužené â pro jednotlivé společnosti

\begin{tabular}{||l|l|l||}
\hline \multicolumn{1}{|c|}{ Společnost } & \multicolumn{1}{c|}{ Odvětví } & $\beta_{Z}$ \\
\hline \hline ČEZ & Electric Utility & 0,71 \\
\hline Zentiva & Pharmacy & 0,77 \\
\hline Philip Morris & Tobaco & 0,58 \\
\hline O2 & Telecom. Services & 1,24 \\
\hline
\end{tabular}

Zdroj: http://www.damodaran.com, výroční zprávy, vlastní výpočty.

\section{Riziková prémie amerického kapitálového trhu}

Riziková prémie trhu je obecně definována jako $E\left(R_{M}\right)-r_{f}$. Ke stanovení $E\left(R_{M}\right)$ využijeme již několikrát zmíněné stránky profesora Damodarana, kde je $E\left(R_{M}\right)$ spočítána jako geometrický průměr výnosnosti indexu S\&P 500 od roku 1928. K 1. 1. 2006 byla $E\left(R_{M}\right)=9,79 \%$ \%. ${ }^{15}$ Snadno dopočítáme rizikovou prémii $E\left(R_{M}\right)-r_{f}=$ $=9,79 \%-4,99 \%=4,80 \%$.

\section{Riziková prémie země}

Poslední proměnná, která nám zbývá ke stanovení, abychom mohli spočítat NVK, je riziková prémie země. Obecně ji lze spočítat různými způsoby. Ve vzorci, který je uveden v kapitole 0, se však bere v úvahu RPZ, která je dána vzorcem:

$$
R P Z=R S Z \cdot \frac{\sigma_{S}}{\sigma_{B}}
$$

kde: $\quad$ RSZ je riziko selhání země;

ó $\quad$ je volatilita trhu akcií;

ó $_{\mathrm{B}} \quad$ je volatilita vládních dluhopisů.

Riziko selhání země vypočteme jako rozdíl mezi výnosností podnikových obligací v USA se stejným ratingem, jako má stát, pro nějž rizikovou přirážku země hledáme, a vládními obligacemi USA. Agentura Fitch Ratings ${ }^{16}$ dávala k 1. 1. 2006 ČR rating A. ${ }^{17}$ Průměrná výnosnost amerických 10letých podnikových obligací se stejným ratingem byla

$14 \mathrm{http} / / /$ www.stern.nyu.edu/ adamodar/pc/archives/betas05.xls (jedná se o data publikovaná v lednu 2006).

$15 \mathrm{http} / / /$ www.stern.nyu.edu/ adamodar/pc/datasets/histretSP.xls (jedná se o data publikovaná v lednu 2006).

16 Nejčastěji se doporučuje pracovat s ratingem společností Moody's a Standard and Poor's, Přesto byla zvolena Fitch Ratings, protože při přepočítání ratingových stupňů na stejnou stupnici, udává Fitch Ratings $\mathrm{v}$ tomto případě průměr ratingů od společností Moody's a Standart and Poor's.

17 Rating lze nalézt na adrese http://www.fitchratings.com/corporate/ratings/issuer_content.cfm?issr_id=80442222, rating ČR od společnosti Fitch Ratings se za poslední roky nezměnil a je dlouhodobě A. 
k 1. 1. $20065,22 \% .{ }^{18}$ Výnosnost 10letých vládních obligací v USA byla k 1. 1. 2006 $4,99 \%$ (viz kapitola 0 ). Volatilita se vyjadřuje podle směrodatných odchylek výnosností. V našich podmínkách je však obtížné získávat aktuální volatility trhu akcií a trhu vládních dluhopisů. $\mathrm{V}$ takových to př́padech je možné nahradit podíl volatilit koeficientem $1,5 .{ }^{19}$ Hodnota rizikové prémie země je pak $R P Z=(5,22 \%-4,99 \%) \cdot 1,5=0,35 \%$. Protože diskontní míru kalkulujeme z pohledu českého investora, musíme upravit ještě hodnotu o rozdíl v dlouhodobě prognózované inflaci mezi Českou republikou a USA. Za tento rozdíl se obvykle dosazuje $1 \%$. Riziková prémie země je tedy $1,35 \%$.

\section{Výpočet NVK}

Nejprve spočítáme NVK pro společnost ČEZ. Dle výše uvedeného vzorce pro NVK dostáváme $\quad N V K=r_{f}+\beta \cdot R P T+R P Z=4,99 \%+0,71 \cdot 4,8 \%+1,62 \%=9,75 \%$. NVK společnosti ČEZ stanovené pomocí dat $\mathrm{z}$ amerického kapitálového trhu a za použití úpravy o rizikovou prémii země jsou $9,75 \%$. Obdobně postupujeme u dalších společností. Výsledky našich výpočtů jsou shrnuty v následující tabulce:

\section{Tabulka č. 6: NVK pro jednotlivé společnosti}

\begin{tabular}{|l|c|}
\hline \multicolumn{1}{|c|}{ Společnost } & NVK (\%) \\
\hline \hline ČEZ & 9,75 \\
\hline Zentiva & 10,04 \\
\hline Philip Morris & 9,12 \\
\hline O2 & 12,29 \\
\hline
\end{tabular}

Pokud bychom měli výpočet shrnout, tak bezrizikovou výnosnost a rizikovou prémii jsme odhadli obvyklým způsobem. Odhad rizikové prémie země jsme si trochu ulehčili a nepočítali jsme s volatilitami trhu akcií a dluhopisů. Místo toho jsme využili př́pustné nahrazení podílu volatilit koeficientem 1,5.

\section{Závěr}

NVK u zvolených společností jsme spočítali pomocí modelu CAPM. V ideálním případě by měl propočet proběhnout na datech domácího kapitálového trhu (myšleno z hlediska oceňovaných společností). Podmínkou je však, aby tento kapitálový trh byl dostatečně rozvinutý. To český kapitálový trh zatím nezaručuje, proto se doporučuje používat data amerického kapitálového trhu a výsledný propočet upravit o rizikovou prémii ČR. Na př́ikladu čtyř společností jsme ukázali, jak odlišné jsou hodnoty jednotlivých přistupů.

V prvním př́stupu, jsme použili rizikovou prémii a bezrizikovou výnosnost českého kapitálového trhu. Za $\hat{a}_{\mathrm{A}}$ jsme dosadili nezadluženou betu pro př́íslušné odvětví vypočtenou profesorem Damodaranem pro Evropu, kterou jsme ale nejprve převedli na zadluženou betu $\mathrm{z}$ hlediska dané společnosti. V druhém př́stupu jsme použili rizikovou prémii, betu a bezrizikovou výnosnost amerického kapitálového trhu. Vzali jsme v úvahu odvětvovou betu a převedli jsme jí na zadlužení konkrétní společnosti. Na závěr jsme výpočet upravili

18 Nepodařilo se mi z veřejně dostupných zdrojů získat přesnou hodnotu k 1. 1. 2006. Uvedená hodnota se vztahuje k 3. 1. 2006 a byla nalezena na http://www.bondsonline.com/Todays_Market/Chart_Center.php?FA= yieldCurve_single\&type $=\mathrm{C} \&$ date $1=1 \% 2 \mathrm{~F} 3 \% 2 \mathrm{~F} 2006$, nicméně odchylka by měla být minimální.

19 Mařík, M. a kol.: Metody oceňování podniku. Praha, Ekopress 2003, s. 187. 
o rizikovou prémii země, ve které uvedená společnost sídlí a převážně působí. V následující tabulce č. 7 jsou přehledně shrnuty rozdíly ve výsledcích.

Tabulka č. 7: Souhrn výsledků - NVK

\begin{tabular}{||l|c|c|c||}
\hline \multicolumn{1}{|c|}{ Společnost } & $\begin{array}{c}\text { NVK (\%, český } \\
\text { kapitálový trh) }\end{array}$ & $\begin{array}{c}\text { NVK (\%, americký } \\
\text { kapitálový trh) }\end{array}$ & Rozdíl (\%) \\
\hline \hline ČEZ & 5,82 & 9,75 & 3,93 \\
\hline Zentiva & 7,01 & 10,04 & 3,03 \\
\hline Philip Morris & 4,97 & 9,12 & 4,15 \\
\hline O2 & 7,12 & 12,29 & 5,17 \\
\hline Průměr & & & 4,07 \\
\hline
\end{tabular}

Vidíme, že pokud vycházíme $\mathrm{z}$ dat amerického kapitálového trhu, dostáváme u zvolených společností vyšší hodnoty, než když vycházíme z dat českého kapitálového trhu. Průměrný rozdíl u vybraných společností byl 4,07 \%. Uvedené závěry naznačují, respektive potvrzují, že pokud odhadce vyjde při odhadu diskontní míry z dat českého kapitálového trhu a neupraví výpočet o dodatečné přirážky, které by zohlednily stav českého kapitálového trhu, dostane výrazně nižší diskontní míru a ceteris paribus vyšší hodnotu společnosti.

Přesnější závěry bychom dostali, pokud bychom vzali v úvahu více společností. NVK u jednotlivých společností by bylo vhodné také upravit o dodatečné prémie a diskonty. Rovněž odhad některých proměnných lze zpřesnit, $v$ ideálním př́padě by si odhad každé prosměnné zasloužil vlastní kapitolu v rozsahu této práce. Nesmíme také zapomenout, že jsme si v řadě případů ulehčili situaci pomocí předpokladů. Přesto závěry práce podporují obecné závěry, že výpočet NVK na základě dat z českého kapitálového bez dodatečných přirážek determinuje výrazně nižší NVK, než když vyjdeme z dat rozvinutých kapitálových trhů.

\section{Literatura}

[1] BREALEY R. A., MYERS S. C.: Teorie a praxe firemních financí. Praha, Computer Press, 2000.

[2] DAMODARAN, A.: Damodaran on Valuation: Security Annalysis for Investment and Corporate Finance. 2nd edition, John Wiley \& Sons, Inc. 2006.

[3] DAMODARAN, A.: The Dark Side of Valuation. Prentice-Hall, Inc. 2001.

[4] COPELAND, T. - KOLLER, T. - MURRIN, J.: Stanovení hodnoty firem. Praha, Victoria publishing, 1995.

[5] KISLINGEROVÁ, E.: Oceňování podniku. 2. vydání, Praha, C. H. Beck, 2001.

[6] MǍ̌íK, M. a kol.: Metody oceňování podniku. Proces ocenéní, základni metody a postupy. 1. vydání, Praha, Ekopress, 2003.

[7] MǍ̌íKOVÁ, P. - MǍ̌íK, M.: Diskontní míra v oceňování. 1. vydání, Praha, Vysoká škola ekonomická v Praze Institut oceňování majetku, 2001.

[8] MAĽÍK, M.: Odhad rizikové prémie kapitálového trhu metodou ex ante jako cesta ke zdokonaleni kalkulaci diskontní míry. Odhadce a oceňování majetku, 2005, roč. 11, č. 4 , s. 6 . 
[9] MLČOCH, J.: Oceňování podniku. Praha, Linde, 1998.

[10] SHARPE, W. F. - Alexander, G. J.: Investice. Praha, Victoria Publishing, 1993.

[11] VALACH, J.: Investiční rozhodování a dlouhodobé financování. 2. přepracované vydání, Praha, Ekopress, 2005.

[12] Skupina ČEZ Výroční zpráva 2005.

[13] Zentiva N.V. Výroční zpráva 2005.

[14] Philip Morris ČR a.s. Výroční zpráva 2005.

[15] ČESKÝ TELECOM, a.s., člen skupiny Telefónica Výroční zpráva 2005.

[16] Ostatní zdroje informací:

[17] Damodaran on-line. [server on-line]. [cit. 2007-04-05]. Dostupné z: $<$ http://www.damodaran.com>.

[18] Yahoo Finance. [server on-line]. [cit. 2007-04-05]. Dostupné z: <http://finance.yahoo.com>.

[19] Fitch Ratings. [server on-line]. [cit. 2007-04-05]. Dostupné z: <http://www.fitchratings.com>.

[20] Patria Online. [server on-line]. [cit. 2007-04-05]. Dostupné z: $<$ http://www.patria.cz $>$.

[21] Burza cenných papírů Praha. [server on-line]. [cit. 2007-04-05]. Dostupné z: $<$ http://www.pse.cz>.

[22] Bondsonline [server on-line]. [cit. 2007-04-05]. Dostupné z: $<$ http://www.bondsonline.com>. 